\title{
Recovery Method and Parameter Optimization of a Pilot Test for Conformance Control Flooding and Thermal Recovery in the Offshore Heavy Oilfield
}

\author{
Yanxia Zhou $\mathbb{D}^{1,2}$ Xiangguo Lu, ${ }^{1,2}$ Bao Cao, ${ }^{1,2}$ Yigang Liu, ${ }^{3}$ Yunbao Zhang, \\ and Xun Zhong ${ }^{4}$ \\ ${ }^{1}$ College of Petroleum Engineering, Northeast Petroleum University, Daqing, Heilongjiang 163318, China \\ ${ }^{2}$ Key Laboratory of Enhanced Oil Recovery of Education Ministry, Northeast Petroleum University, Daqing, \\ Heilongjiang 163318, China \\ ${ }^{3}$ Production Division of Tianjin Branch Company in China Offshore Oil Company, Tanggu 300450, China \\ ${ }^{4}$ College of Petroleum Engineering, Yangtze University, Wuhan, Hubei 430100, China
}

Correspondence should be addressed to Yanxia Zhou; zhouyanxia781023@163.com

Received 28 October 2020; Revised 15 December 2020; Accepted 26 December 2020; Published 14 January 2021

Academic Editor: Shiyuan Zhan

Copyright (C) 2021 Yanxia Zhou et al. This is an open access article distributed under the Creative Commons Attribution License, which permits unrestricted use, distribution, and reproduction in any medium, provided the original work is properly cited.

NB35-2 oilfield is a typical offshore sandstone reservoir with viscous crude oil and high permeability. Due to the inherent severe heterogeneity, the efficiency of conventional water flooding is pretty low and usually accompanied with early water breakthrough. In order to recover the residual oil and better realize its potential, applications of enhanced oil recovery (EOR) technology are necessary. However, the selection of EOR method and related parameters may directly impact the final results and can be noticeably different for different reservoirs; therefore, to optimize the oil production rate and final oil recovery, systematical optimization of every detail based on the condition of a specific reservoir is of key importance. In this paper, physical simulations were first conducted to select the best recovery methods for the target area based on the static geophysical model under the guidance of reservoir engineering theory. Then, detailed development variants for each method were determined by numerical simulation with the support of data obtained from previous pilot tests (polymer gel flooding and thermal fluid huff and puff) conducted in this area. Three exploitation methods were developed for the target well group, including polymer gel flooding (conformance control, Pattern 1), steam huff and puff (thermal recovery method, Pattern 2), and a combination of polymer gel flooding and steam huff and puff (conformance control and thermal recovery, Pattern 3). The numerical simulation result also showed that Pattern 3 yielded the highest oil recovery. Moreover, the amount of additional oil being recovered by applying Pattern 3 was even higher than the total additional oil being extracted by Patterns 1 and 2 . In addition, sensitivity analysis was conducted to rank the most important parameters based on the three Patterns. At last, it is thought that the synergistic effect between conformance control and thermal recovery made more oil recovered, which was intuitively clarified in the mechanism analysis.

\section{Introduction}

At present, the production of terrestrial oil and gas is decreasing year by year, while the oil demand of national industrial construction and people's daily lives is steadily increasing $[1,2]$. However, the good news is the great potentials in offshore oilfields have offered great opportunities to mitigate this issue [3]. Bohai Oilfield is a famous offshore oilfield with huge crude oil reserves in China, with heavy oil occupying about two-thirds of its total reserves. NB35-2 oilfield lies in the center of the Bohai Sea with high permeability (average permeability of most layers around $1000 \sim 5000 \times 10^{-3} \mu \mathrm{m}^{2}$ ) and serious heterogeneity, and its crude oil is of high viscosity (450 950 $\mathrm{mPa} \cdot \mathrm{s})$. The distances between the injection wells 


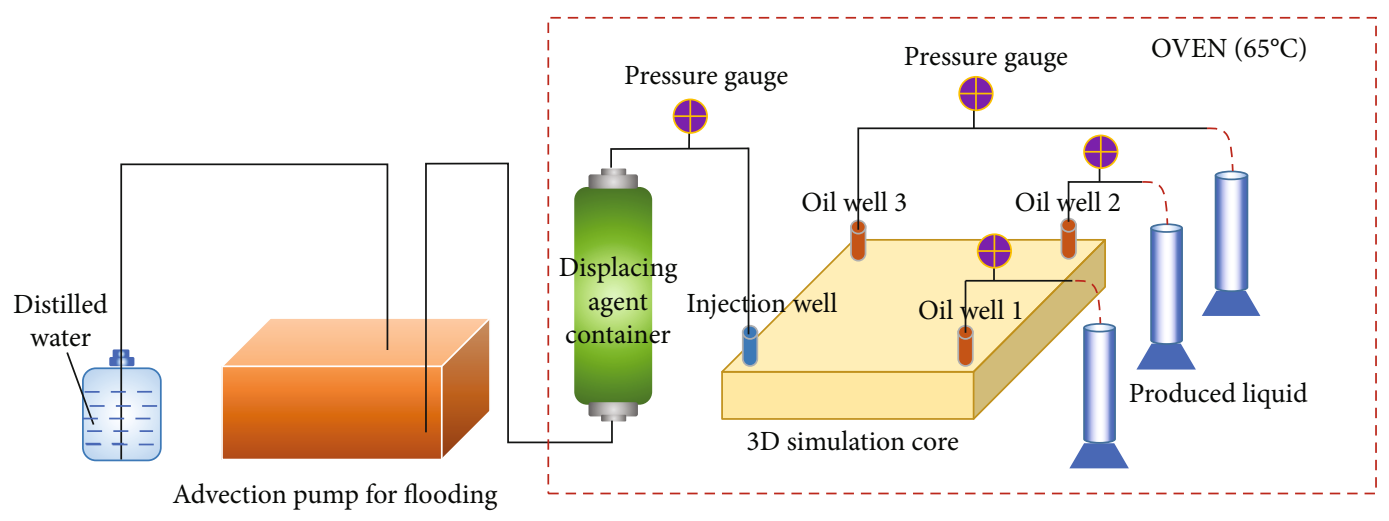

Figure 1: Schematic diagram of experimental set-up.

and the production wells (at least $300 \mathrm{~m}$ ) are always large; most importantly, the water flooding oil recovery is pretty low (about 15\%) in this area. Therefore, effective exploitation technologies should be taken to recover the residual oil after conventional water flooding. At present, steam huff and puff or steam flooding is the normally applied technology to exploit heavy oil reservoirs [4-7]. However, in the process of steam huff and puff, formation pressure may suffer from significant loss. Therefore, the recovery factor of conventional steam huff and huff is very low [8-10]. Although steam flooding effectively supplies formation pressure, the steam fluid channeling is always a serious challenge because of the reservoir anisotropy and high mobility of the steam, which not only decreases the sweep volume and thermal efficiency but also harms the normal operation of oil well artificial lifting system [11]. In recent years, polymer flooding and polymer gel flooding technologies received much attention because of their better adaptability, lower cost, and higher efficiency. Since 1996, Daqing Oilfield has developed an industrial application of polymer flooding technology, and the application scale is enlarging year by year. The increment proportion of oil production by polymer flooding towards total oil output is also rising. According to the statistics, more than $1000 \times 10^{4} \mathrm{t}$ additional oil has been recovered in the continuous ten years [12-14]. Another success story of conformance control is that Henan Oilfield has been carried out using polymer gel before the polymer flooding since 2004. After the conformance control, the injection pressure rose, apparent infectivity index dropped, and the water injection profile was noticeably improved. The polymer concentration of produced liquid in the block reduced greatly, leading to significant oil increment and water cut reduction [15]. Though single conformance control flooding and single thermal recovery have achieved good effect in increasing oil recovery and decreasing water cut, now, there is still a concerned question for petroleum technologist and scientist whether the combined operation ("conformance control flooding and thermal recovery") can get a better effect. To maximize the effectiveness of the combined operation, recovery methods and parameter optimization were carried out in this work focusing on injection and production process in the target well group and analysis of field test results. This work follows the guide of oil reservoir engineering theory to establish the static geophysical model and perform the dynamic numerical modeling on the basis of some fundamental information and data of the target well group in the NB35-2 oilfield.

\section{Materials and Methods}

2.1. Experimental Materials. The polymer used is partially hydrolyzed polyacrylamide with relative molecular weight of $1900 \times 10^{4} \mathrm{~g} / \mathrm{mole}$ provided by Daqing refining chemical company. The cross-linking agent is an organic chromium with $2.89 \mathrm{wt} . \% \mathrm{Cr}^{3+}$. The simulated oils are mixtures of heavy crude oil and kerosene in order to prepare oils with different viscosities $(850 \mathrm{mPa} \cdot \mathrm{s}, 428 \mathrm{mPa} \cdot \mathrm{s}, 120 \mathrm{mPa} \cdot \mathrm{s}$, and $23 \mathrm{mPa} \cdot \mathrm{s}$ at $\left.50^{\circ} \mathrm{C}\right)$. Formation water with salinity of $4441.76 \mathrm{mg} / \mathrm{L}$ obtained from NB35-2 was applied to prepare the solutions. The experiment core is a $3 \mathrm{D}$ simulation model with heterogeneous inner layer [16]. Its external dimension is height $x$ width $\times$ length of $4.5 \mathrm{~cm} \times 30 \mathrm{~cm} \times 30 \mathrm{~cm}$. This core sample is glued by quartz sand and epoxy and surrounded by a strong epoxy resin layer, so it has high pressure resistance. Each core is composed of three layers with different permeability (gas permeability, $3200 \times 10^{-3} \mu \mathrm{m}^{2}, 1600 \times 10^{-3} \mu \mathrm{m}^{2}$, and $800 \times 10^{-3} \mathrm{~mm}^{2}$ ) to simulate the heterogeneity of the real formation. The thickness of each layer is around $1.5 \mathrm{~cm}$.

2.2. Instrument and Facilities. The viscosity of flooding agent is tested by DV-II Brinell viscosity instrument at the rotation speed of $6 \mathrm{r} / \mathrm{min}$. The experiment displacement facilities mainly include advection pump, pressure gauge, and displacing agent container. Except the advection pump, the other facilities are placed in an oven with a constant temperature of $65^{\circ} \mathrm{C}$. The schematic diagram of experimental set-up is shown in Figure 1.

2.3. Physical Simulation. There were four large-size artificial cores for physical simulation of four displacement schemes, including water flooding ( $1^{\text {st }}$ scheme), thermal recovery after water flooding ( $2^{\text {nd }}$ scheme), conformance control after water flooding ( $3^{\text {rd }}$ scheme), and conformance control flooding and thermal recovery after water flooding ( $4^{\text {th }}$ scheme). Before the start of the experiment, all four cores were saturated with formation water after being evacuated and then 


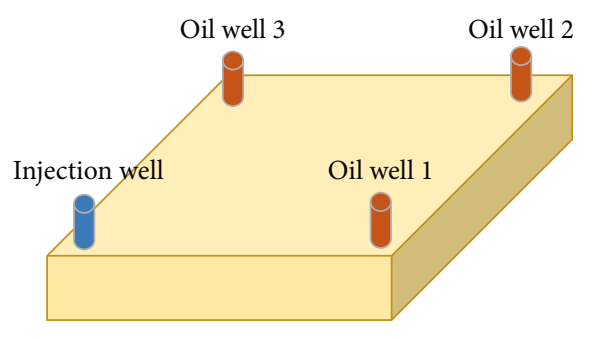

(a)

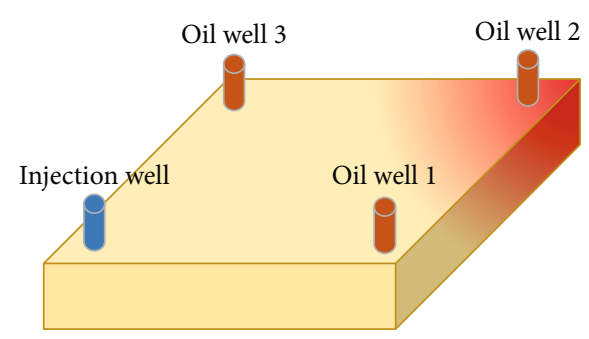

(b)

FIGURE 2: 3D-simulated physical model of 1/4 inverted nine-spot pattern: (a) used in water flooding and Pattern 1 (conformance control flooding); (b) used in Pattern 2 (thermal recovery) and Pattern 3 (conformance control flooding and thermal recovery).

saturated original oil ( $850 \mathrm{mPa} \cdot \mathrm{s})$ in $1^{\text {st }}$ and $3^{\text {rd }}$ scheme. Due to the fact it is difficult to simulate the effect of injected hot fluid on the viscosity of crude oil near the bottom of the well, for the first time, this paper used the crude oil of different viscosity saturated in the vicinity of the thermal recovery well to reflect the range of action of the thermal fluid. [17] On the basis of previous physical simulation experience, the heating radius of the thermal fluid is $3 / 10$ distance between the water well and oil well. In this effected range by thermal fluid, three kinds of viscosity distribution were followed by $23 \mathrm{mPa} \cdot \mathrm{s}$, $120 \mathrm{mPa} \cdot \mathrm{s}$, and $428 \mathrm{mPa} \cdot \mathrm{s}$ from oil well. The viscosity of other range in the $3 \mathrm{D}$ physical model still keeps original crude viscosity with $850 \mathrm{mPa}$.s. The detailed experimental procedures are as follows:

(1) $1^{\text {st }}$ scheme: ordinary water flooding until the water cut of produced liquid reaches $98 \%$

(2) $2^{\text {nd }}$ scheme: conducting water flooding at injection well and thermal recovery technology at oil wells until the water cut of produced liquid reaches $98 \%$

(3) $3^{\text {rd }}$ scheme: for water well, $0.03 \mathrm{PVCr}^{3+}$ polymer gel (concentration of polymer of $1200 \mathrm{mg} / \mathrm{L}$, mass ration of polymer gel to $\mathrm{Cr}^{3+}$ of 180 to 1) was injected after the ordinary water flooding to water cut reaches $98 \%$, and then subsequent water flooding was conducted until the water cut of produced liquid reaches $98 \%$

(4) $4^{\text {th }}$ scheme: for water well, $0.03 \mathrm{PVCr}^{3+}$ polymer gel (concentration of polymer of $1200 \mathrm{mg} / \mathrm{L}$, mass ration of polymer gel to $\mathrm{Cr}^{3+}$ of 180 to 1) was injected until water cut reaches $98 \%$ after the ordinary water flooding and thermal recovery technology at oil wells, and then subsequent water flooding was conducted until the water cut of produced liquid reaches $98 \%$

Because shearing action is inevitable during the process of preparation and injection, therefore, to better simulate the real situation, the polymer solution was exposed to shearing action before the addition of $\mathrm{Cr}^{3+}$. The viscosity retention rate is around $60 \%$.

2.4. Numerical Simulation. In order to further illustrate the synergistic effect between conformance control and thermal recovery method, a series of numerical simulation $[18,19]$ was conducted to analyze the three different recovery
TABLE 1: The experiment results of recovery ratio.

\begin{tabular}{lccccc}
\hline Parameter & $\begin{array}{c}\text { Scheme } \\
\text { contents }\end{array}$ & $\begin{array}{c}\text { Working } \\
\text { viscosity of } \\
\text { polymer gel } \\
(\mathrm{mPa} \cdot \mathrm{s})\end{array}$ & $\begin{array}{c}\text { Oil } \\
\text { saturation } \\
(\%)\end{array}$ & Total & Increment \\
\hline 1 & $\begin{array}{c}1^{\text {st }} \\
\text { scheme } \\
2^{\text {nd }} \\
\text { scheme } \\
3^{\text {rd }}\end{array}$ & - & 78.5 & 8.8 & - \\
3 & $\begin{array}{c}\text { scheme } \\
4^{\text {th }}\end{array}$ & 23.3 & 78.5 & 11.6 & 2.8 \\
4 & 22.8 & 78.1 & 17.9 & 5.1 \\
\hline
\end{tabular}

Note: taking the recovery of scheme 1 as the comparing standard, the increment of other schemes recovery can be calculated.

methods, polymer gel flooding (conformance control, Pattern 1), steam huff and puff (thermal recovery method, Pattern 2), and the combination of polymer gel flooding and steam huff and puff (conformance control flooding and thermal recovery, Pattern 3). First, the classic geologic model of NB35-2 oilfield was built using the three-dimensional geologic modeling software of Petrel. Then, CMG numerical simulation software (STARS and chemical flooding modules) was applied to optimize the injection and production parameter. In this part, the basic input parameters were obtained by fitting with the results of physical simulation results.

2.5. The Field Test. By combined operation with the best injection and production parameters from numerical simulation, a field test is conducted in the NB35-2 oilfield.

\section{Results}

3.1. Experimental Result Analysis. Figure 2 is the schematic diagram of the $3 \mathrm{D}$ physical model with an inverted ninespot pattern.

In the 3D-simulated physical model with the inverted nine-spot pattern, water flooding, conformance control flooding, thermal recovery, and combined operation ("conformance control flooding and thermal recovery") were carried out. Table 1 shows the experiment results of the recovery ratio.

As seen from Table 1, production patterns do affect the ultimate recovery ratio. Compared with water flooding, the 


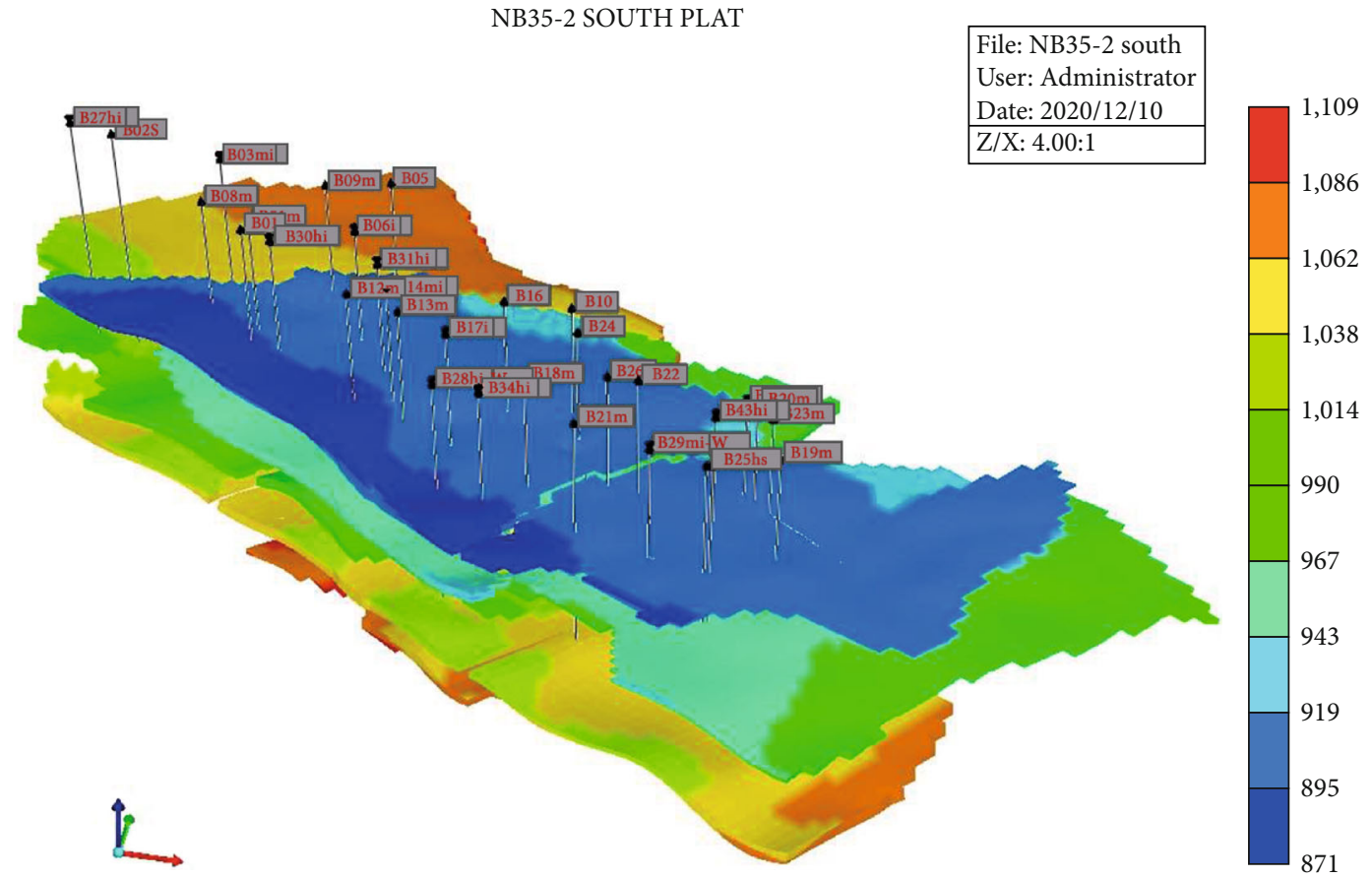

Figure 3: Numerical simulation model.

development effect of "thermal recovery" and "conformance control flooding" is better. The recovery increment of thermal recovery is $2.8 \%$, compared to $5.1 \%$ for profile control flooding and $9.2 \%$ for combined operation. It can be seen that the recovery ration increment of combined operation is the highest. The reason is that the combined operation has a synergistic effect on oil production. On the one hand, conformance control flooding of the combined operation plugged the reservoir layer with high permeability. And subsequent oil displacing agent enters the middle and low permeability layer, expanding the sweep volume. On the other hand, thermal recovery enhanced the reservoir temperature and reduced the oil viscosity, thus decreasing the flow resistance of oil. Therefore, higher recovery is achieved in the combined operation.

\subsection{Numerical Result Analysis}

3.2.1. Reservoir Geologic Model. NB35-2 oilfield is located in the Bohai central waters, and the depth of the water is about $12 \mathrm{~m}$. The oilfield is a multiple nose-like structure reservoir composed of three types of traps which are semi-anticline, complicated fault, and slope belt. The oilfield has the characteristics of shallow burial, abundant reserves, complex fluid property, high viscosity and density, low sulfur content, low solidification point, and medium wax content. The oilfield was put into production in September 2005. Up to now, there are 25 oil wells and 1 gel injection well. The daily oil production is $220 \mathrm{~m}^{3} / \mathrm{d}$, the ratio of total oil output to original oil in place (OOIP) is $1.5 \%$, and the oil recovery rate is as low as $0.3 \%$.

The dynamic model of NB35-2 oilfield was established with CMG imported from the static model in Petrel. In the model, the input of the parameters includes well number

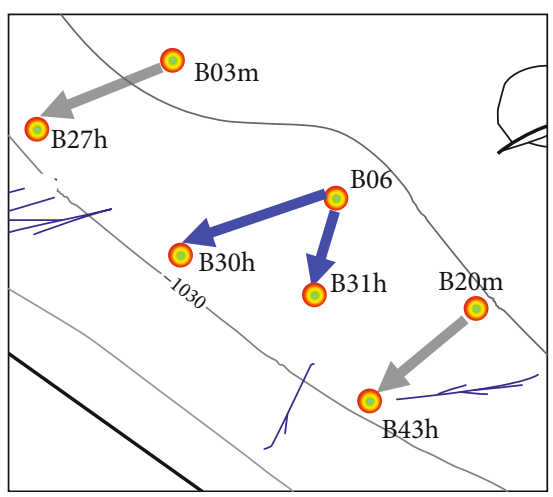

FIgURE 4: The schematic diagram of the B6 well group. The blue arrow represents the target study well group, and the gray arrow represents the nonstudy well group around the target one.

database, subzone database, breakpoint point database, performance dynamic data of oil and water wells (well history data), well-log information, reservoir fluid property, and sedimentary facies data (as shown in Figure 3). In the model, grid number is $\mathrm{NX} \times \mathrm{NY} \times \mathrm{NZ}(129 \times 50 \times 62)=399900$, the planar grid is $50 \times 50$, and longitudinal grid is $1-2 \mathrm{~m}$.

\subsubsection{The Effect Contrast with the Three Production Patterns}

(1) As an example of the B6 well group (as shown in Figure 4), the oil increment effect of the three kinds of production patterns which were conformance control flooding, thermal recovery, and combined operation (conformance control flooding \& thermal recovery) was compared. 
(2) Conformance control flooding: according to real production situation of the oilfield, in the numerical simulate research, B30h well started to produce oil on February 11, 2015, while B31h well on August 1, 2015. At the same time, polymer gel injection was conducted for conformance control in B6 well.

(i) Scheme design: the influence factors of oil increment effect in the conformance control flooding by polymer gel include polymer concentration, slug size, and interval time of the polymer injection. The injection scheme of conformance control flooding by polymer gel was designed by use of the orthogonal numerical test. Each influence factor has two levels (i.e., designed value, as shown in Table 2). Orthogonal design table $L_{4}\left(2^{3}\right)$ is adopted to design schemes, as shown in Table 3.

(ii) Selection of Evaluation index: accumulative oil increment, production-injection ratio, and recovery ratio increment of the well group are the technical indexes to evaluate the effect of conformance control flooding. Therefore, the three evaluation indexes were integrated into a comprehensive evaluation index, as shown in the Equation (1). The comprehensive evaluation index can be as the evaluation index of the orthogonal test.

$$
\phi=\alpha R_{z y}+\beta R_{c t}+\gamma R_{c c}
$$

where $\phi$ is the comprehensive evaluation index of different development modes, including Pattern 1 (conformance control flooding), Pattern 2 (thermal recovery), and Pattern 3 (conformance control flooding and thermal recovery); $R_{z y}$ is the accumulative oil increment $\left(10^{4} \mathrm{~m}^{3}\right) ; R_{c t}$ is the production-injection ratio; $R_{c c}$ is the recovery ratio increment (\%); and $\alpha, \beta, \gamma$ are the weight coefficients of accumulative oil increment, production-injection ratio, and recovery ratio increment, generally being $1 / 3$, respectively.

The comprehensive evaluation index is higher, the production-injection parameters are superior, and the economic benefit of the development modes (Pattern 1, Pattern 2, or Pattern 3) will be better.

(iii) The effect analysis of oil increment: program result and comprehensive evaluation index are showed in Table 3. The intuitive analysis table is shown in Table 4.

As shown in Table 4, in the orthogonal numerical test, the values of the best levels for polymer concentration, slug size, and interval time of the polymer injection are $3000 \mathrm{mg} / \mathrm{L}$, $0.08 \mathrm{PV}$, and 12 months, respectively. According to the simulation, the combination of optimal levels was able to yield an
TABLE 2: Orthogonal design factors and their level values in profile control flooding.

\begin{tabular}{lccc}
\hline Level & $\begin{array}{c}\text { Polymer } \\
\text { concentration } \\
(\mathrm{mg} / \mathrm{L})\end{array}$ & $\begin{array}{c}\text { Factor } \\
\text { Slug size }\end{array}$ & $\begin{array}{c}\text { Interval time of } \\
\text { polymer injection } \\
(\text { month })\end{array}$ \\
\hline 1 & 2500 & 0.06 & 9 \\
2 & 3000 & 0.08 & 12 \\
\hline
\end{tabular}

accumulative oil increment of $1.41 \times 10^{4} \mathrm{~m}^{3}(1.88 \%)$, a production-injection ratio of 2.48 , and a comprehensive evaluation index of 1.92. From the difference of the mean value between the maximum and minimum in Table 4, the primary and secondary order of injection parameters to development effect is slug size $(\mathrm{PV})>$ polymer concentration $(\mathrm{mg} / \mathrm{L})>$ interval time of polymer injection (month).

(3) Thermal recovery: numerical simulation on the B6 well group was also carried out multiple thermal fluid huff, and puff was conducted in oil wells (B30h and B31h) while water flooding was conducted in injection well (B6 well).

According to practical production situation of the oilfield, in the numerical simulate research, B30h well and B31h (in the B6 well group) started to thermal fluid huff and puff, respectively, on February 11 and August 1, in 2015. The injection well started water flooding at the same time.

(a) Scheme design: in order to optimize the parameters in thermal recovery, the orthogonal numerical test is carried out to analyze the influence factors. Under overall considering, there are five factors, i.e., steam injection velocity, shut-in time, steam injection temperature, the cycle time of thermal fluid huff and puff, and steam injection quality in a cycle. Each influence factor has four levels, as shown in Table 5. The orthogonal design table $L_{16}\left(4^{5}\right)$ is adopted to design schemes, as shown in Table 6.

(ii) The effect analysis: experiment scheme and the comprehensive evaluation index (according to Equation (1)) of B30h well in B6 group are shown in Table 6. The intuitive analysis table is shown in Table 7.

From Table 7, we can see that the optimal levels of steam injection velocity, shut-in time, steam injection temperature, the cycle time of thermal fluid huff and puff, and the steam injection quantity in a cycle were, respectively, $150 \mathrm{t} / \mathrm{d}$, $4 \mathrm{~d}, 260^{\circ} \mathrm{C}, 18$ months, and $3500 \mathrm{t}$, respectively. After the combination of optimal levels was able to yield an accumulative oil increment of $1.902 \times 10^{4} \mathrm{~m}^{3}(2.701 \%)$, a productioninjection ratio of 2.431 , and a comprehensive evaluation index of 2.345. From the difference of mean value between the maximum and minimum in Table 4, the primary and secondary order of injection parameters to development effect is the cycle time of thermal fluid huff and puff (month) $>$ the 
TABLE 3: The conformance control flooding scheme and effect of B6 well group.

\begin{tabular}{lccccccc}
\hline Parameter & $\begin{array}{c}\text { Polymer } \\
\text { concentration } \\
(\mathrm{mg} / \mathrm{L})\end{array}$ & Slug size $(\mathrm{PV})$ & $\begin{array}{c}\text { Interval time of } \\
\text { polymer injection } \\
(\mathrm{month})\end{array}$ & $\begin{array}{c}\text { The result of scheme } \\
\text { Accumulative oil } \\
\text { increment }\left(10^{4} \mathrm{~m}^{3}\right)\end{array}$ & $\begin{array}{c}\text { Production- } \\
\text { injection ratio }\end{array}$ & $\begin{array}{c}\text { Recovery ratio } \\
\text { increment }(\%)\end{array}$ & $\begin{array}{c}\text { Comprehensive } \\
\text { evaluation index }\end{array}$ \\
\hline 1 & 2500 & 0.06 & 9 & 0.918 & 2.112 & 1.224 & 1.418 \\
2 & 2500 & 0.08 & 12 & 1.291 & 2.515 & 1.721 & 1.842 \\
3 & 3000 & 0.06 & 12 & 1.012 & 2.136 & 1.349 & 1.499 \\
4 & 3000 & 0.08 & 9 & 1.354 & 2.384 & 1.806 & 1.848 \\
\hline
\end{tabular}

TABLE 4: Intuitive analysis table of B6 well group.

\begin{tabular}{|c|c|c|c|}
\hline Parameter & Polymer concentration $(\mathrm{mg} / \mathrm{L})$ & Slug size $(\mathrm{PV})$ & Interval time of polymer injection (month) \\
\hline Mean value 1 & 1.630 & 1.459 & 1.633 \\
\hline Mean value 2 & 1.674 & 1.845 & 1.671 \\
\hline Prior level & 3000 & 0.08 & 12 \\
\hline $\begin{array}{l}\text { Difference of mean value between the } \\
\text { maximum and minimum }\end{array}$ & 0.043 & 0.387 & 0.038 \\
\hline
\end{tabular}

TABLE 5: Orthogonal design factors and level values in the thermal fluid huff and puff.

\begin{tabular}{cccccc}
\hline Level & $\begin{array}{c}\text { Steam injection } \\
\text { velocity }(\mathrm{t} / d)\end{array}$ & Shut-in time $(\mathrm{d})$ & $\begin{array}{c}\text { Factor } \\
\text { Steam injection } \\
\text { temperature }\left({ }^{\circ} \mathrm{C}\right)\end{array}$ & $\begin{array}{c}\text { Cycle time of thermal fluid } \\
\text { huff and puff (month) }\end{array}$ & $\begin{array}{c}\text { Steam injection quantity } \\
\text { in a cycle }(\mathrm{t})\end{array}$ \\
\hline 1 & 120 & 2 & 260 & 9 & 3500 \\
2 & 130 & 3 & 265 & 12 & 4000 \\
3 & 140 & 4 & 270 & 18 & 4500 \\
4 & 150 & 5 & 275 & 5000 \\
\hline
\end{tabular}

steam injection quantity in a cycle $(\mathrm{t})>$ steam injection velocity $(\mathrm{t} / \mathrm{d})>$ shut-in time $(\mathrm{d})>$ steam injection temperature $\left({ }^{\circ} \mathrm{C}\right)$.

Similarly, for B31h well, the best level of steam injection velocity, shut-in time, steam injection temperature, cycle time of thermal fluid huff and puff, and the steam injection quantity in a cycle is, respectively, $140 \mathrm{t} / \mathrm{d}, 3 \mathrm{~d}, 275^{\circ} \mathrm{C}, 18$ months, and $3500 \mathrm{t}$. After numerical simulation calculation with the value of the best level, the accumulative oil increment is $2.471 \times 10^{4} \mathrm{~m}^{3}$, production-injection ratio is 3.695 , recovery efficiency increment is $4.304 \%$, and comprehensive evaluation index is 3.490. The primary and secondary order of injection parameters to development effect is the cycle time of thermal fluid huff and puff (month) $>$ steam injection temperature $\left({ }^{\circ} \mathrm{C}\right)>$ steam injection velocity $(\mathrm{t} / \mathrm{d})>$ shut-in time $(d)>$ the steam injection quantity in a cycle $(t)$.

Then, after numerical simulation calculation of the B6 well group (B30h oil well and B31h oil well) with the value of the best level, the accumulative oil increment is $2.19 \times 10^{4} \mathrm{~m}^{3}$, production-injection ratio is 0.6 , recovery efficiency increment is $3.56 \%$, and comprehensive evaluation index is 2.92 .

(4) Combined operation (conformance control flooding and thermal recovery): the combined operation (con- formance control flooding and thermal recovery) is carried out in the B6 well group. Multiple thermal fluid huff and puff was conducted in oil wells (B30h and B31h), while conformance control flooding with polymer gel was conducted in injection well (B6 well) at the same time.

According to practical production situation of the oilfield, in the simulation research, B30h and B31h wells (in the B6 well group) started to multi thermal fluid huff and puff for oil production, respectively, on February $11^{\text {th }}$ and August $1^{\text {st }}$, in 2015. The injection well started conformance control flooding with polymer gel at the same time.

(i) Scheme design: the combined operation result is affected by the comprehensive function from injection and production parameters. In order to solve the question of parameter optimization, the orthogonal numerical test is carried out to analyze the influence parameter. Through overall considering, nine factors are considered, in which six parameters are from thermal recovery development, i.e., steam injection velocity, shut-in time, injection quantity in a cycle, steam injection temperature, and the cycle time of thermal fluid huff and puff. And the three parameters are from conformance control development, 


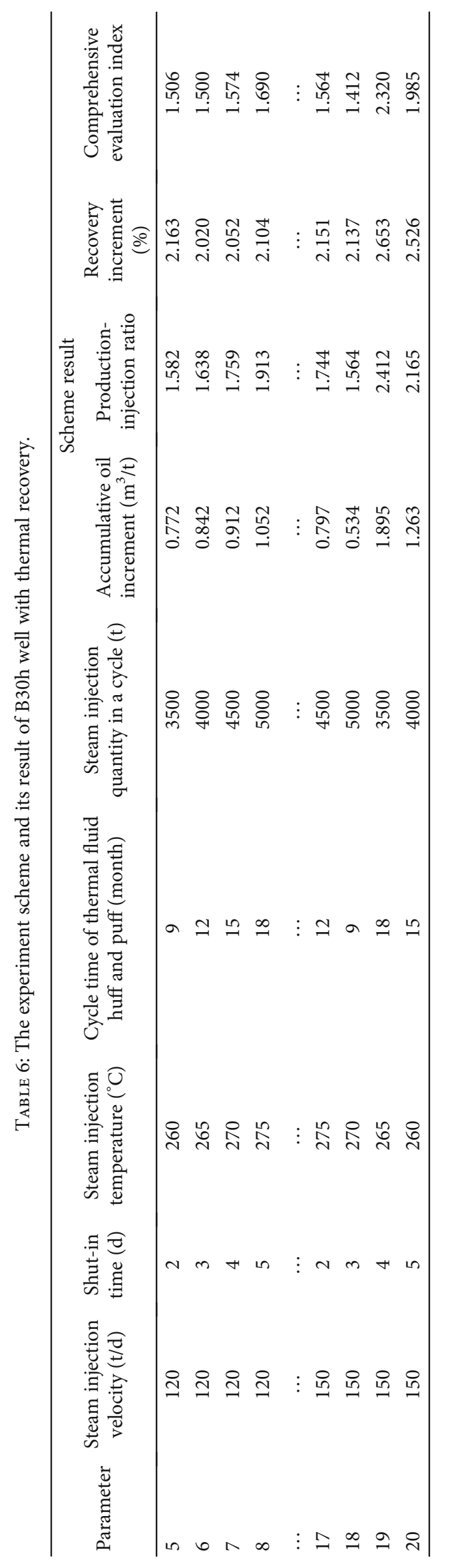


TABLE 7: Intuitive analysis table of B30 well in thermal recovery experiment.

\begin{tabular}{lccccc}
\hline Parameter & $\begin{array}{c}\text { Steam injection } \\
\text { velocity }(\mathrm{t} / \mathrm{d})\end{array}$ & $\begin{array}{c}\text { Shut-in } \\
\text { time }(\mathrm{d})\end{array}$ & $\begin{array}{c}\text { Steam injection } \\
\text { temperature }\left({ }^{\circ} \mathrm{C}\right)\end{array}$ & $\begin{array}{c}\text { Cycle time of thermal fluid } \\
\text { huff and puff }(\mathrm{month})\end{array}$ & $\begin{array}{c}\text { Steam injection } \\
\text { quantity in a cycle }(\mathrm{t})\end{array}$ \\
\hline Mean value 1 & 1.568 & 1.636 & 1.702 & 1.438 & 1.560 \\
Mean value 2 & 1.621 & 1.633 & 1.701 & 1.743 & 1.702 \\
Mean value 3 & 1.655 & 1.713 & 1.632 & 1.923 & 1.529 \\
Mean value 4 & 1.820 & 1.681 & 260 & 0.485 & 3500 \\
Prior level & 150 & 4 & 0.073 & 0.273 \\
$\begin{array}{l}\text { Difference of mean value between } \\
\text { the maximum and minimum }\end{array}$ & 0.252 & 0.080 & &
\end{tabular}

TABLe 8: Orthogonal design factors and level values in the combined operation.

\begin{tabular}{|c|c|c|c|c|c|c|c|c|c|}
\hline \multirow[b]{2}{*}{ Parameter } & \multicolumn{9}{|c|}{ Influence factor } \\
\hline & $\begin{array}{c}\text { Steam } \\
\text { injection } \\
\text { velocity }(\mathrm{t} / \mathrm{d})\end{array}$ & $\begin{array}{l}\text { Shut-in } \\
\text { time }(d)\end{array}$ & $\begin{array}{l}\text { Injection } \\
\text { quantity in } \\
\text { a cycle }(\mathrm{t})\end{array}$ & $\begin{array}{c}\text { Steam } \\
\text { injection } \\
\text { temperature } \\
\left({ }^{\circ} \mathrm{C}\right)\end{array}$ & $\begin{array}{l}\text { Cycle time } \\
\text { of thermal } \\
\text { fluid huff and } \\
\text { puff (month) }\end{array}$ & $\begin{array}{c}\text { Polymer } \\
\text { concentration } \\
(\mathrm{mg} / \mathrm{L})\end{array}$ & $\begin{array}{l}\text { Slug size } \\
\text { (PV) }\end{array}$ & $\begin{array}{l}\text { Interval time } \\
\text { of polymer } \\
\text { injection } \\
\text { (month) }\end{array}$ & $\begin{array}{l}\text { Production- } \\
\text { injection ratio }\end{array}$ \\
\hline 1 & 120 & 2 & 3500 & 260 & 9 & 2000 & 0.04 & 6 & 0.8 \\
\hline 2 & 130 & 3 & 4000 & 265 & 12 & 2500 & 0.06 & 9 & 0.9 \\
\hline 3 & 140 & 4 & 4500 & 270 & 15 & 3000 & 0.08 & 12 & 1 \\
\hline 4 & 150 & 5 & 5000 & 275 & 18 & 3500 & 0.10 & 15 & 1.1 \\
\hline 5 & & & & & & & & & 1.2 \\
\hline 6 & & & & & & & & & 1.3 \\
\hline 7 & & & & & & & & & 1.4 \\
\hline 8 & & & & & & & & & 1.5 \\
\hline
\end{tabular}

i.e., polymer concentration, slug size, and the interval time of polymer injection. Considering the conservation of formation energy in the injection and production operations, production-injection ration is also considered. By way of these parameters, the effect to the production result of the combined operation can be analyzed. The production-injection ration is set 8 levels. Other parameters are set 4 levels, as shown in Table 8 . The orthogonal design table $L_{32}($ $\left.8^{1} \times 4^{8}\right)$ is adopted to get scheme design, as shown in Table 9.

(ii) The effect analysis

Experiment scheme and its comprehensive evaluation index (according to Equation (1)) of B6 well group are shown in Table 9. The intuitive analytical table is shown in Table 10.

From Table 10, we can see that the best level of steam injection velocity, shut-in time, steam injection quantity in a cycle, steam injection temperature, the cycle time of thermal fluid huff and puff, polymer concentration, slug size, interval time of conformance control flooding, and the productioninjection ratio is, respectively, $150 \mathrm{t} / \mathrm{d}, 3 \mathrm{~d}, 3500 \mathrm{t}, 275^{\circ} \mathrm{C}, 18$ months, $3000 \mathrm{mg} / \mathrm{L}, 0.04 \mathrm{PV}, 6$ months, and 1.5. After numerical simulation calculation with the value of the best level, the accumulative oil increment is by $5.26 \times 10^{43}$, the production-injection ratio by 6.29 , recovery efficiency increment by $7.36 \%$, and comprehensive evaluation index by 6.30 . From the difference of the mean value between maximum and minimum in Table 10, the primary and secondary order of injection parameters to development effect is the cycle time of thermal fluid huff and puff (month) $>$ production -injection ratio $>$ cycle time of the steam injection quantity $(\mathrm{t})>$ slug size $(\mathrm{PV})>$ shut-in time $(\mathrm{d})>$ steam injection temperature $\left({ }^{\circ} \mathrm{C}\right)>$ polymer concentration $(\mathrm{mg} / \mathrm{L})>$ interval time of polymer injection (month) $>$ steam injection velocity $(\mathrm{t} / \mathrm{d})$.

(5) The effect contrast of three production patterns: numerical simulation of the B6 well group was carried out with three production patterns, i.e., conformance control flooding, thermal recovery, and combined operation (conformance control flooding and thermal recovery). The result is shown in Table 11 and Figure 5.

Table 11 and Figure 5, in the three production patterns, i.e., profile control flooding, thermal recovery, and combined operation, the comprehensive evaluation index of the combined operation is the highest and has the best oil increment. It indicates in the process of conformance control flooding that the conformance control flooding agent first entered into the high permeable layer and blocked off the high permeability stripe. At the same time in the thermal recovery process, the thermal fluid huff and puff can heat the reservoir, increase 


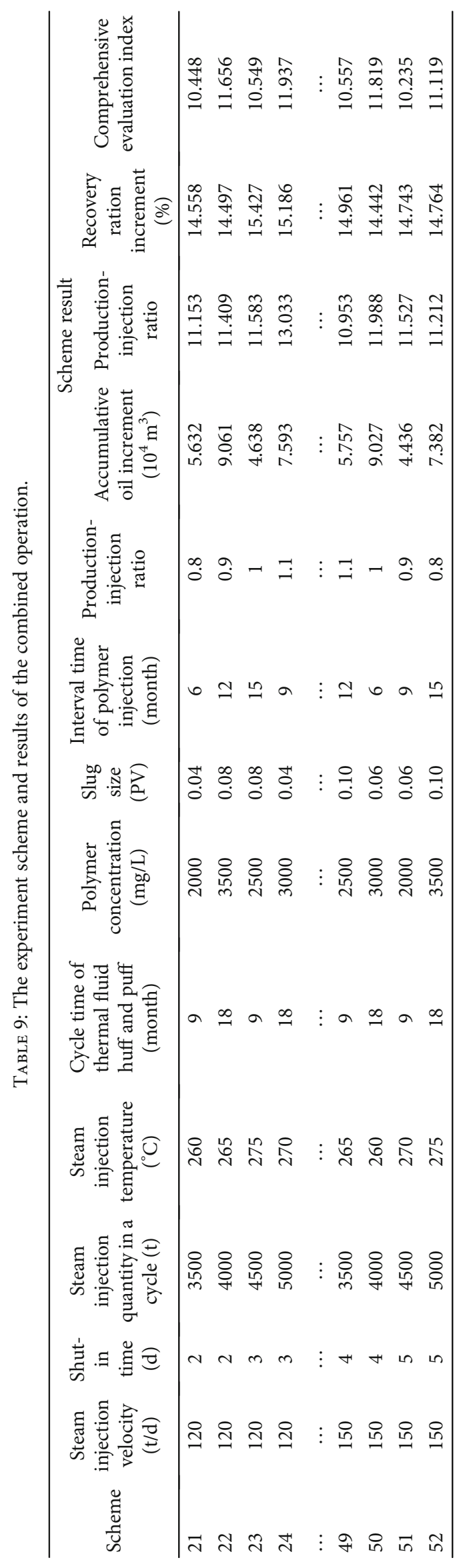


TABLE 10: Intuitive analysis table of the B6 well group with combined operation.

\begin{tabular}{|c|c|c|c|c|c|c|c|c|c|}
\hline Parameter & $\begin{array}{l}\text { Steam } \\
\text { injection } \\
\text { velocity } \\
(\mathrm{t} / \mathrm{d})\end{array}$ & $\begin{array}{l}\text { Shut- } \\
\text { in } \\
\text { time } \\
\text { (d) }\end{array}$ & $\begin{array}{l}\text { Steam } \\
\text { injection } \\
\text { quantity in } \\
\text { a cycle }(\mathrm{t})\end{array}$ & $\begin{array}{c}\text { Steam } \\
\text { injection } \\
\text { temperature } \\
\left({ }^{\circ} \mathrm{C}\right)\end{array}$ & $\begin{array}{l}\text { Cycle time of } \\
\text { thermal fluid } \\
\text { huff and puff } \\
\text { (month) }\end{array}$ & $\begin{array}{c}\text { Polymer } \\
\text { concentration } \\
(\mathrm{mg} / \mathrm{L})\end{array}$ & $\begin{array}{l}\text { Slug } \\
\text { size } \\
(\mathrm{PV})\end{array}$ & $\begin{array}{l}\text { Interval time } \\
\text { of polymer } \\
\text { injection } \\
\text { (month) }\end{array}$ & $\begin{array}{l}\text { Production- } \\
\text { injection } \\
\text { ratio }\end{array}$ \\
\hline Mean value 1 & 11.151 & 11.157 & 11.472 & 11.025 & 10.610 & 11.122 & 11.266 & 11.176 & 10.658 \\
\hline Mean value 2 & 11.151 & 11.278 & 11.232 & 11.122 & 10.825 & 11.090 & 11.182 & 11.138 & 10.933 \\
\hline Mean value 3 & 11.124 & 11.053 & 10.940 & 11.223 & 11.333 & 11.195 & 11.126 & 11.112 & 11.152 \\
\hline Mean value 4 & 11.168 & 11.107 & 10.950 & 11.224 & 11.825 & 11.187 & 11.021 & 11.167 & 11.098 \\
\hline Mean value 5 & & & & & & & & & 11.217 \\
\hline Mean value 6 & & & & & & & & & 11.224 \\
\hline Mean value 7 & & & & & & & & & 11.391 \\
\hline Mean value 8 & & & & & & & & & 11.515 \\
\hline Prior level & 150 & 3 & 3500 & 275 & 18 & 3000 & 0.04 & 6 & 1.5 \\
\hline $\begin{array}{l}\text { Difference of mean } \\
\text { value between the } \\
\text { maximum and } \\
\text { minimum }\end{array}$ & 0.044 & 0.225 & 0.532 & 0.199 & 1.215 & 0.106 & 0.245 & 0.064 & 0.857 \\
\hline
\end{tabular}

TABLE 11: The effect contrast of three production patterns of the B6 well group.

\begin{tabular}{lccccc}
\hline $\begin{array}{l}\text { Well } \\
\text { group }\end{array}$ & Production pattern & $\begin{array}{c}\text { Accumulative oil } \\
\text { increment }\left(10^{4} \mathrm{~m}^{3}\right)\end{array}$ & $\begin{array}{c}\text { Production- } \\
\text { injection ratio }\end{array}$ & $\begin{array}{c}\text { Recovery efficiency } \\
\text { increment (\%) }\end{array}$ & $\begin{array}{c}\text { Comprehensive } \\
\text { evaluation index }\end{array}$ \\
\hline B6 well & $\begin{array}{c}\text { Conformance control } \\
\text { flooding }\end{array}$ & 1.41 & 2.48 & 1.88 & 1.92 \\
group & Thermal recovery & 2.19 & 3.06 & 3.56 & 2.94 \\
& Combined operation & 5.26 & 6.29 & 7.36 & 6.30 \\
\hline
\end{tabular}

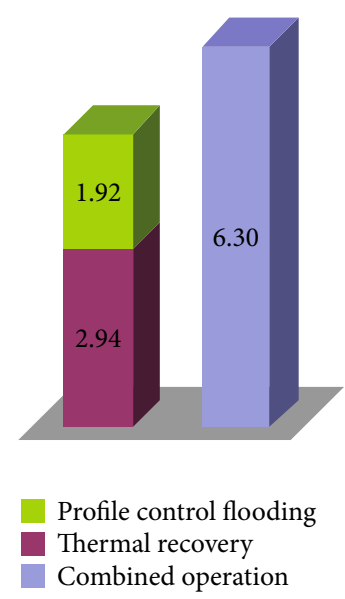

Figure 5: The comprehensive evaluation index of three production patters of the B6 well group.

the formation temperature, reduce the oil viscosity, and decrease flow resistance. Because there is a synergistic effect in the combined operation, its oil production increment is much better than the total of both thermal recovery and conformance control flooding.

3.3. The Effect Analysis of the Field Test. As an example of the B6 well group, polymer weak gel flooding was carried out in
B6 injection well on July 13, 2016. Its injection allocation is $120 \mathrm{~m}^{3} / \mathrm{d}$, the mass injection concentration of polymer at wellhead is $2800 \mathrm{mg} / \mathrm{L}$, the wellhead viscosity is $64.0 \mathrm{~Pa} \cdot \mathrm{s}$, and the wellhead pressure is from $3.9 \mathrm{MPa}$ to $10.39 \mathrm{MPa}$. On October 1, 2017, the protection slug was injected, with the concentration of $40,000 \mathrm{mg} / \mathrm{L}$, the viscosity of $150 \mathrm{mPa} \cdot \mathrm{s}$, and injection allocation of $80 \mathrm{~m}^{3} / \mathrm{d}$. Then, the wellhead pressure rose from 7.15 MPa to 9.9Mpa (as shown in Figure 6). This indicated that after the polymer gel entered into the reservoir, it first entered into the high permeability layer and had retention. This can lead to reduce overcurrent section, increase flow resistance, enhance wellhead injection pressure, and enlarge suction hydraulic difference between medium and low permeability layers. So the suction quantity increased and made a valid use of them. That achieved the purpose of conformance control flooding.

Take B31h well for example, after conformance control flooding in B6 well on July 1, 2016, the daily oil production of $\mathrm{B} 31 \mathrm{~h}$ has a distinct rise, with the water cut greatly decreasing. After the shut-in time in the second cycle of thermal fluid huff and puff of in March 2017, the daily oil production rose by a great margin, with the water cut rapidly decreasing (as shown in Figure 7). In cut-off by August 2019, the accumulative oil production of combined operation (conformance control flooding and thermal recovery) reached $4.18 \times 10^{4}$ $\mathrm{m}^{3}$. Compared with water flooding development (the accumulative oil production by numerical simulation being 1.19 


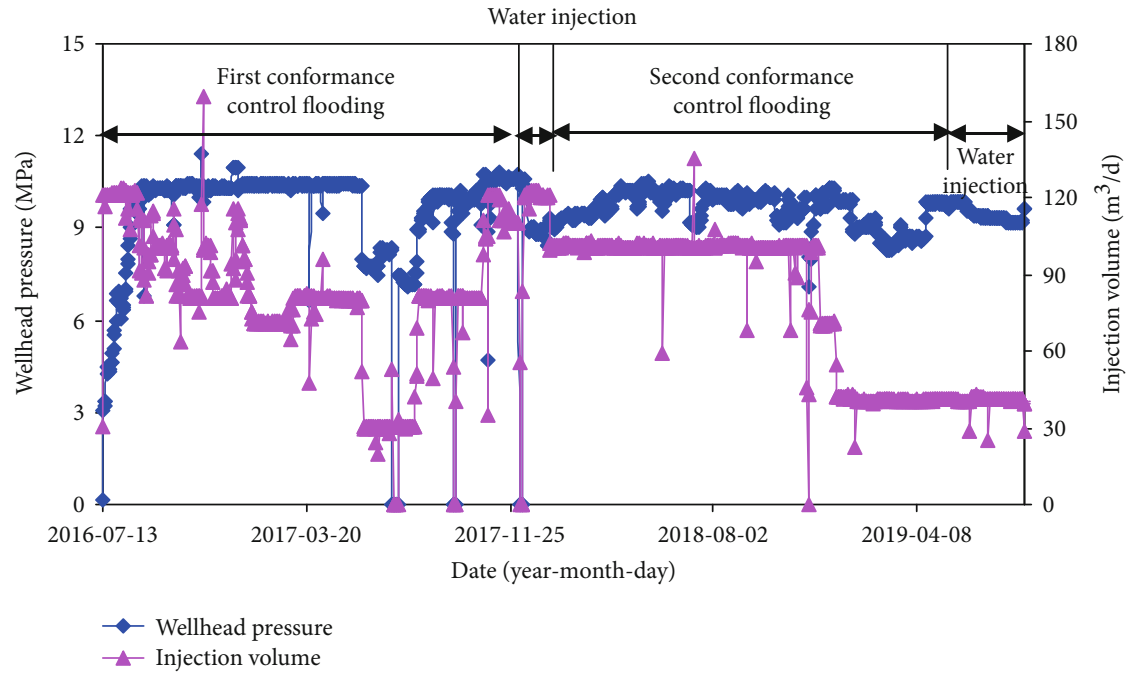

FIgURE 6: Production profiles of the B6 well.

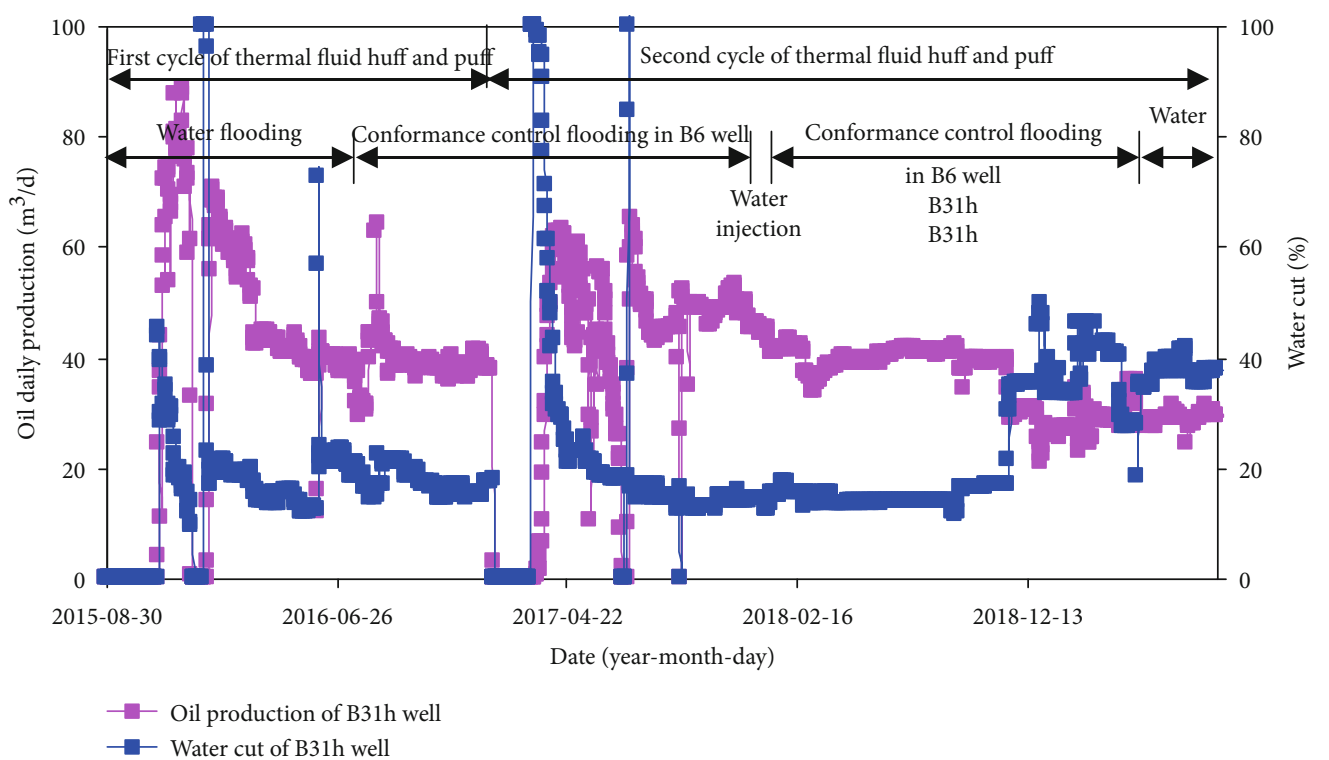

FIgURE 7: Production profiles the B31 well.

$\times 10^{4} \mathrm{~m}^{3}$ ), the accumulative oil increment reached $2.09 \times 10^{4}$ $\mathrm{m}^{3}$. The accumulative oil production with conformance control flooding can reach $2.21 \times 10^{4} \mathrm{~m}^{3}$. Its accumulative oil increment is $1.02 \times 10^{4} \mathrm{~m}^{3}$ compared with water flooding development. The accumulative oil production with thermal recovery is $1.93 \times 10^{4} \mathrm{~m}^{3}$. Its accumulative oil increment is $0.74 \times 10^{4} \mathrm{~m}^{3}$ compared with water flooding development, as shown in Figure 8. Thus, it can be seen that the accumulative oil increment by combined operation is much higher than the sum of oil increment by conformance control flooding and thermal recovery. It is illustrated that after thermal fluid huff and puff of B31h well, the reservoir nearby the well bottom was heated, with the viscosity of crude oil declining and the seepage resistance decreasing. Together with the effect of conformance control flooding of B6 well,

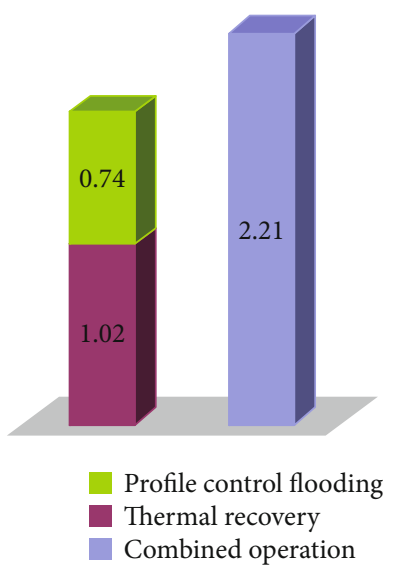

FIGURE 8: Comparison of accumulative oil increment $\left(10^{4} \mathrm{~m}^{3}\right)$. 


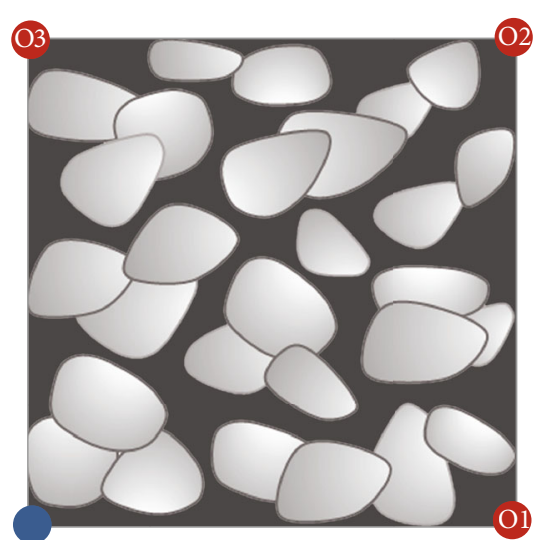

Injection well

- Production well O1, O2, O3

$\checkmark$ Rock

* Effective range of thermal fluid

(a)

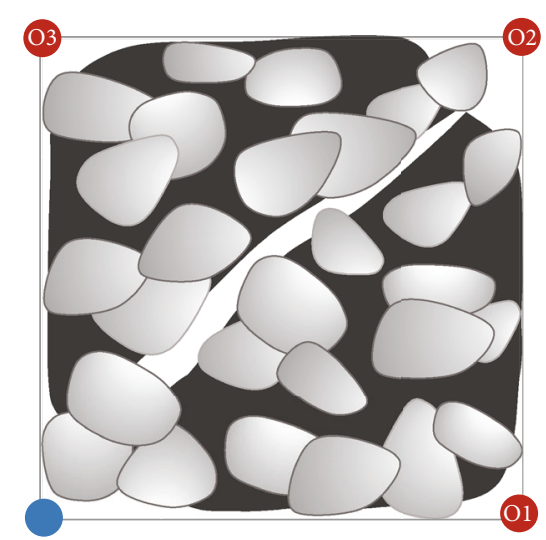

Injection well

- Production well O1, O2, O3

Rock

* Effective range of thermal fluid

(b)

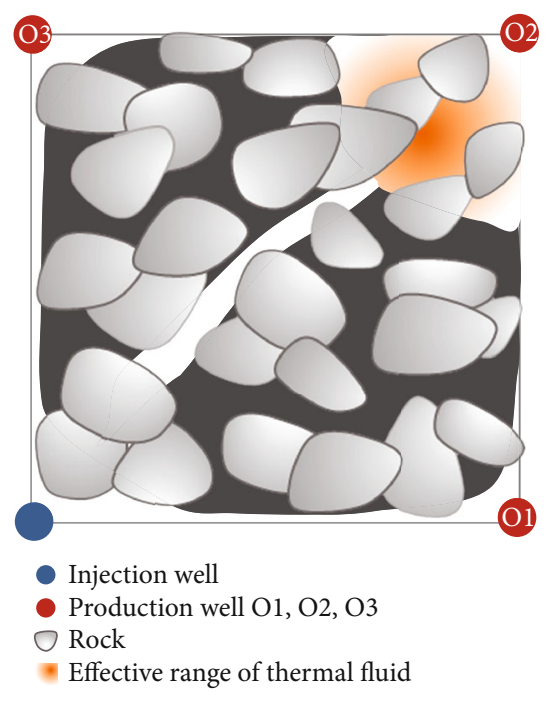

(c)

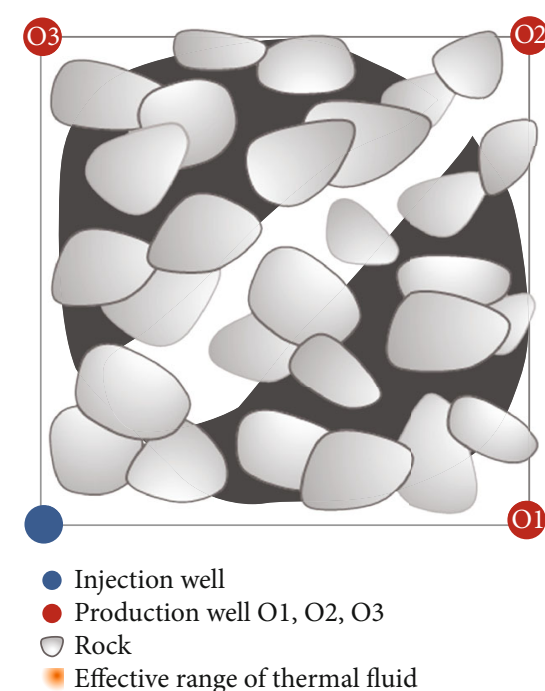

(d)

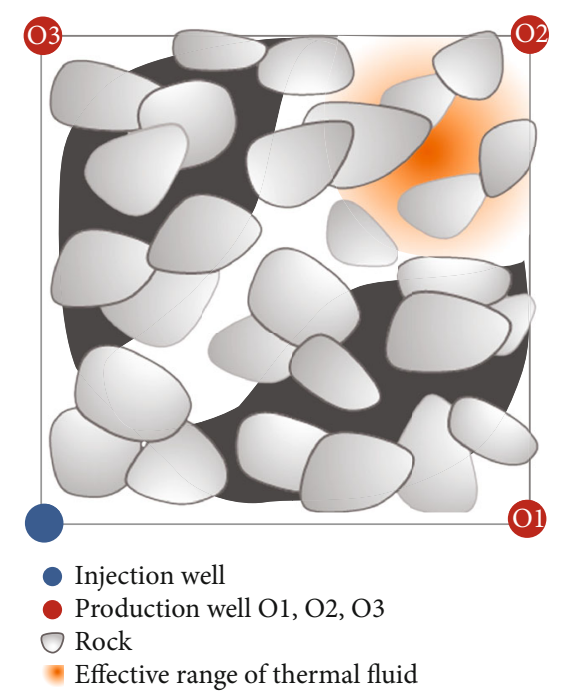

(e)

FIGURE 9: Mechanism diagram. (a) Crude oil distribution in the original reservoir. (b) Crude oil distribution after water flooding. (c) Crude oil distribution after thermal recovery. (d) Crude oil distribution after conformance control. (e) Crude oil distribution after combined operation ("conformance control flooding and thermal recovery").

the synergistic effect of both of them can achieve a better productive result.

3.4. Mechanism Analysis. From the experimental and numerical results and field test, the combined operation ("conformance control flooding and thermal recovery") obtained a good oil recovery. The mechanism diagram is shown in Figure 9. Compared with original reservoir (Figure 9(a)), after the water flooding (Figure 9(b)), only the crude oil in the near-well zone and the straight area between the injection well and production wells are produced, especially forming an obvious channel between the injection well and its diagonal O2 oil well. Due to the high viscosity of the crude oil, the mobility ratio of the oil and water is relatively high, which greatly reduced the sweep coefficient of the injected water, resulting in poor water flooding effect. If thermal recovery
(Figure 9(c)) was carried out in the diagonal O2 oil well of injection well after water flooding, it is obvious that the crude oil around the $\mathrm{O} 2$ oil well is produced largely due to the injected thermal fluid decreasing the viscosity of the crude oil near it result in lower flow resistance. If conformance control (Figure 9(d)) was carried out in injection well after water flooding, compared with water flooding (Figure 9(b)), more oil was produced due to the increased sweep coefficient of oil displacing agent and the main produced area was the same as water flooding (Figure 9(b)) but with a larger scope. And the crude oil located on the main line between the injection well and its diagonal well is mostly produced forming a thicker channel. If combined operation (Figure 9(e)) was carried out with conformance control of injection well and thermal recovery of the diagonal $\mathrm{O} 2$ oil well of injection well, a better recovery result was obtained when more oil was 
produced. In particular, a good development effect was obtained around the thermal recovery well due to the low viscosity of the crude oil in this area and the oil displacing agent swept more area, which was called synergistic effect achieving better development results.

\section{Conclusions}

In this paper, through the comparison results of physical simulation and numerical simulation of three development methods (conformance control, Pattern 1; thermal recovery method, Pattern 2; and conformance control and thermal recovery, Pattern 3), it is proved that Pattern 3 yielded the highest oil recovery and it recovered more oil than the sum of Pattern 1 and Pattern 2 used separately. Through the mechanism analysis, the synergistic effect was considered to achieve the better development results. So the development method of Pattern 3 (conformance control and thermal recovery) can be used as an effective development mode for heavy oil reservoir. This work provides theoretical guidance for its further application. At the same time, the optimal injection parameters of three different development modes are obtained by numerical simulation, which can guide the phased development of the target reservoir to a certain extent. The details are as follows:

(1) In the production pattern with conformance control flooding, the value of the best level of polymer concentration, slug size, and interval time of the conformance control flooding is $3000 \mathrm{mg} / \mathrm{L}, 0.08 \mathrm{PV}$, and 12 months, respectively. The primary and secondary order of injection parameters to development effect is $\operatorname{slug}$ size $(\mathrm{PV})>$ polymer concentration $(\mathrm{mg} / \mathrm{L})>$ interval space polymer injection (month)

(2) In the development pattern of B31h well with thermal recovery, the value of the best level of steam injection velocity, shut-in time, steam injection temperature, cycle time of thermal fluid huff and puff, and the steam injection quantity in a cycle is, respectively, $150 \mathrm{t} / \mathrm{d}$, $4 \mathrm{~d}, 260^{\circ} \mathrm{C}, 18$ months, and $3500 \mathrm{t}$. The primary and secondary order of injection parameters to development effect is the cycle time of thermal fluid huff and puff (month) $>$ the steam injection quantity in a cycle $(\mathrm{t})>$ steam injection velocity $(\mathrm{t} / \mathrm{d})>$ shut-in time $(\mathrm{d})$ $>$ steam injection temperature $\left({ }^{\circ} \mathrm{C}\right)$

(3) In the development pattern of combined operation (conformance control flooding and thermal recovery), the value of the best level of steam injection velocity, shut-in time, steam injection quantity in a cycle, steam injection temperature, cycle time of thermal fluid huff and puff, polymer concentration, slug size, interval time of profile control flooding, and production-injection ratio is, respectively, $150 \mathrm{t} / \mathrm{d}$, $3 \mathrm{~d}, 3500 \mathrm{t}, 275^{\circ} \mathrm{C}, 18$ months, $3000 \mathrm{mg} / \mathrm{L}, 0.04 \mathrm{PV}, 6$ months, and 1.5. The primary and secondary order of injection parameters to development effect is cycle time of thermal fluid huff and puff (month) > production - injection ratio $>$ cycle time of the steam injection quantity $(\mathrm{t})>$ slug size $(\mathrm{PV})>$ shut-in time (d) $>$ steam injection temperature $\left({ }^{\circ} \mathrm{C}\right)>$ polymer concentration $(\mathrm{mg} / \mathrm{L})>$ interval time of polymer injection (month) $>$ steam injection velocity $(\mathrm{t} / \mathrm{d})$

(4) Through the research by both physical and numerical simulation, the synergistic effect exists in the combined operation. Its oil production increment effect is much better than the sum of the conformance control flooding and thermal recovery

\section{Data Availability}

There is no additional data available for this study.

\section{Conflicts of Interest}

The authors declare no conflict of interest.

\section{Acknowledgments}

The authors would like to thank the research programs of Major national projects of the thirteenth five-year plan: Integrated technology research and demonstration of water shutoff and profile modification for multizone water channeling in offshore Bohai Oilfield with high viscosity oil and high water cut (project number: 2016ZX05058-003-010) and National Science Foundation: basic research of salt-resistant polymer on its reservoir adaptability and improvement methods (project number: 51574086) for the financial support. We are very grateful to Production Division of Tianjin Branch Company in China Offshore Oil Company for providing the Petro and CMG software for this study.

\section{References}

[1] G. P. Thiel, L. D. Tow, L. D. Banchik, H. W. Chung, and J. H. Lienhard V, "Energy consumption in desalinating produced water from shale oil and gas extraction," Desalination, vol. 366, no. 15, pp. 94-112, 2015.

[2] A. S. Alshehry and M. Belloumi, "Energy consumption, carbon dioxide emissions and economic growth: the case of Saudi Arabia," Renewable and Sustainable Energy Reviews, vol. 41, pp. 237-247, 2015.

[3] H. Rui, C. Li, F. Peng et al., "Development of industry performance metrics for offshore oil and gas project," Journal of Natural Gas Science and Engineering, vol. 39, pp. 44-53, 2017.

[4] K. Guo, H. Li, and Z. Yu, "In-situ heavy and extra-heavy oil recovery: a review," Fuel, vol. 185, pp. 886-902, 2016.

[5] C. Huang, S. Huang, L. Cheng, S. Wei, and Z. Chen, "Experimental study on steam flooding of horizontal wells in heterogeneous thin heavy oil reservoir," Special Rreservoir, vol. 22, no. 2, pp. 108-110+156, 2015.

[6] Y. Liu, J. Zou, X. Meng et al., "Treatment technology of steam breakthrough for offshore heavy oil reservoirs developed by huff and puff with multi-component thermal fluid," in SPE Asia Pacific Enhanced Oil Recovery Conference, pp. 11-13, Kuala Lumpur, Malaysia, August 2015.

[7] G. Pan, J. Chen, C. Zhang et al., "Combined technology of weak gel flooding assisting thermal huff and puff enhances oil recovery for offshore heavy oil field," in SPE Annual 
Technical Conference and Exhibition, pp. 26-28, Dubai, UAE, September 2016.

[8] S. Huang, M. Cao, and L. Cheng, "Experimental study on the mechanism of enhanced oil recovery by multi-thermal fluid in offshore heavy oil," Internatioal Journal of Heat and Mass Transfer, vol. 122, pp. 1074-1084, 2018.

[9] R. Sun, Y. Sun, K. Fan et al., "Experiment studies on horizontal well- $\mathrm{N}_{2}$-viscosity depressant - steam stimulation for shallow thin super-heavy oil reservoirs," in SPE Trinidad and Tobago Section Energy Resources Conference, Port of Spain, Trinidad and Tobago, June 2018.

[10] Q. Huang, P. Guo, and J. Zhang, "Application status of CO2 huff and puff in heavy oil reservoirs at home and abroad," Journal of Chengde Petroleum College, no. 2, pp. 4-6+16, 2008.

[11] Y. Gao, E. Guo, D. Shen, and B. Shen, "Air injection technology in the later stage of steam assisted gravity drainage in super heavy oil reservoir," Petroleum Exploration and Development, vol. 46, no. 1, pp. 109-115, 2019.

[12] L. Sun, X. Wu, W. Zhou, X. Li, and P. Han, "Technologies of enhancing oil recovery by chemical flooding in Daqing Oilfield, NE China," Petroleum Exploration and Development, vol. 45, no. 4, pp. 673-684, 2018.

[13] X. Zhong, Y. Wang, H. Pu, W. Li, S. Yin, and K. Ling, "Commercial implementation of chemical flooding in Daqing Oilfield, China, and its future," in SPE EOR Conference at Oil and Gas West Asia, pp. 3/26-3/28, Muscat, Oman, 2018.

[14] S. Gao, Z. Jiang, K. Zhang et al., "High concentration polymer flooding field test with well infilling to change fluid flowing direction after polymer flooding," in SPE EOR Conference at Oil and Gas West Asia, pp. 3/21-3/23, Muscat, Oman, 2016.

[15] X. Wu, S. Zhang, C. Xiong et al., "Successful field test of a new polymer flooding technology for improving heavy oil reservoir recovery - case study of strongly heterogeneous and multilayer conglomerate heavy oil reservoir XJ6," in SPE EOR Conference at Oil and Gas West Asia, pp. 3/21-3/23, Muscat, Oman, 2016.

[16] X. Lu, Z. Gao, and W. Yan, "Experimental study of factors influencing permeability of artificial core abstract," Petroleum Geology \& Oilfield Development in Daqing, vol. 13, no. 4, pp. 53-55, 1994.

[17] Y. Zhou, X. Lu, K. Xie, Y. Liu, Y. Zhang, and R. Wang, “A physical simulation method for realizing thermal recovery process of indoor core," 2015, Invention patent, ZL201510835157.0. (Authorized).

[18] X. Liu, F. Zhang, K. Huang, D. Cui, and Y. Huang, "Discussion about the thermal recovery of NB35-2 offshpre heavy oilfield," Reservoir Evaluation and Development, vol. 1, no. 1-2, pp. 6163, 77, 2011.

[19] J. Ai, W. Wang, and J. Wang, "Optimization design of injextion-production parameters of steam stimulation wells," Petroleum Geology \& Oilfield Development in Daqing, vol. 23, no. 1, pp. 65-66, 2004. 